\title{
Visualizing Data in the Quantitative Comparison of Ancient Texts: a Study of Paul, Epictetus, and Philodemus
}

\author{
Paul Robertson
}

In a recent monograph, ${ }^{1}$ I argued for formal overlaps between several roughly contemporary texts in what I termed a shared "socio-literary sphere": the letters of the Christian apostle Paul, the Stoic popular philosopher Epictetus' Discourses, and the Epicurean scholar Philodemus' On Death and On Piety. Further, certain other writings - Seneca's Natural Questions, Letter to the Hebrews, and 4 Maccabees - were likewise found to have formal similarities close to Paul's letters. These findings stood in contrast to several other types of texts often likened to Paul's letters, such as formal Greco-Roman orations (e.g., Aelius Aristides' Panathenaic Orations, Dio Chrysostom's orations) and sectarian Jewish literature (e.g., the Damascus Document), which were found in fact to be quite dissimilar to Paul's letters.

This comparative project was based on a polythetic approach to classification, whereby each text was defined not by essential terms such as genre or ethnicity but by a wide set of non-essential literary criteria. These criteria were inductively derived, formal, second-order characteristics that I hand-coded into spreadsheets and visualized graphically. In this way, providing second-order criteria that I inductively derived and empirically applied, I demonstrated that certain texts should be understood as closely related, based on methods and findings that were transparent, quantifiable, and therefore able to be visualized clearly. I further argued that this type of approach and conclusion was preferable to previous, existing approaches based on more essentialized understandings of literature. ${ }^{2}$ In other words, I provided second-order theorization, application, and data-based conclusions from the digital humanities around biblical literature in its literary, ancient Mediterranean context.

1 Robertson, Paul, Paul's Letters and Contemporary Greco-Roman Literature: Theorizing a New Taxonomy, Leiden: Brill, 2016.

2 Robertson, Paul's Letters, 10-66. 
The use of second-order characteristics, which is to say characteristics that are not native to the data in question but rather derived and created by the scholar for descriptive purposes and/or to answer particular types of questions, is essential. While categories native to the ancient world do exist that can productively characterize texts, notably those of advanced rhetorical theory such as found in Demosthenes, an attempt to connect data points which are subconsciously or indirectly related must use modern categories at some conceptual remove from the data. ${ }^{3}$ In other words, while Paul, Epictetus, and Philodemus likely were aware of certain prescriptions of advanced rhetorical theory, they were probably unaware of how their social practices, beliefs, and writing style could be grouped into general types. ${ }^{4}$ Indeed, categorization and classification is often a second-order operation, as our task as scholars is to seek patterns, overlaps, and connections not explicitly held or recognized within our data sets.

In my previous monograph, however, I provided only the general summary of these data sets and my empirical findings on them. ${ }^{5}$ I did not show how each of the second-order, literary criteria comprising my polythetic classificatory framework manifested in my comparanda (Paul, Epictetus, Philodemus). In what follows below, I make a more specific case for my particular literary criteria, demonstrating how they manifest in texts written by Paul, Epictetus, and Philodemus, and then pairing this digital approach with qualitative analysis. This type of work is an essential supplement to my original monograph, as it details how second-order criteria can be derived from texts, and how these texts are understood specifically within my wider polythetic frameworks.

\section{Socio-Literary Spheres: Theory and Classification}

I contend that we should understand, describe, and compare ancient literature according to polythetic classification, a nuanced system of description allowing for comparison across such essentialized lines as ethnicity (Jew vs. Greek), geography (eastern vs. western), or genre (history vs. gospel vs. oratory). I have specifically argued that instead of these essentialized categories of literature (e.g., "Greek historical" vs. "Jewish apocalyptic"), texts and authors are better understood and categorized in what I've termed "socio-literary spheres", which are semi-autonomous fields of literate, cultural production that are

3 Robertson, Paul's Letters, 89-118.

4 Robertson, Paul's Letters, 77- 88.

5 Robertson, Paul's Letters, 121-169. 
determined by particular intersections of texts' form, content, and social purpose. ${ }^{6}$ These intersections are complex, as form, content, and social purpose are each comprised of many constituent elements. As such, we need a method of description that not only captures this complexity in a nuanced fashion, but also allows us to compare texts so described in this multifarious way. This type of comparison serves my wider contention, that we should be looking to describe pan-Mediterranean types of beliefs and social practices that can be generalized in terms of macro trends present across essentialized categories.

Essential to comparison is description and classification. ${ }^{7}$ How any two things compare - i.e., in which ways, and to what extent - hugely relies on how the comparanda are understood and consequently described. My approach to comparison relies on the notion of polythetic classification. Polythetic classification, or polythetism, is a form of description whereby the object in question is classified according to a wide set of characteristics or criteria, no single one of which determines whether or not the piece of data belongs to a category. Instead, clusters of criteria are determinative for belonging to a particular category. Polythetism is thus a complex and nuanced form of description and classification: the issue is how many characteristics or criteria are needed to belong to a category according to a particular scholar's definition of that category. Polythetic classification around categories is a matter of "more and less", with no black and white determination, which makes it especially suitable for nuanced description and thus comparison of complex data sets.

6 The language of "fields" is drawn from Bourdieu, Pierre, Outline of a Theory of Practice, Cambridge: Cambridge University Press, 1977. My understanding of literature as existing within, and to be described through, embodied social practices (i.e., practice theory, or site ontology) is drawn particularly from Schatzki, Theodore, The Site of the Social:A Philosophical Account of the Constitution of Social Life and Change, Philadelphia, PA: University of Pennsylvania Press, 2002. Schatzki's work draws particularly from the work of Heidegger and Wittgenstein; for the latter, see further discussion below. Finally, Bourdieu's modern framework of literate fields should be paired with the Foulcauldian notion of "discourse" for work in the ancient world: while literate fields in the ancient world were even more rarified than they are in modernity, Foucault's notion of "discourse" as constructed entities via power relations usefully broadens Bourdieu's modernity-specific fields around aristocratic taste toward a more general explanatory framework pertaining to how groupings of the relatively educated and powerful create their own discourse conventions. See Foucault, Michel, The Archaeology of Knowledge, trans. A.M. Sheridan Smith, New York and London: Routledge, 2002. I thank Claire Clivaz for this essential theoretical broadening.

7 The desire for theoretical insights derived from description and classification (albeit of much different kinds of theories, data, and frameworks as discussed here) animated many of the early giants in religious studies' approach to comparative religion, See "Frazer", "Campbell" and "Eliade", in: Tarot, Camille, Michel Despland, L'émergence des sciences de la religion. La monarchie de Juillet: un moment fondateur, Paris: L'Harmattan, 1999. 
When we describe a text's style, for instance, we use a host of descriptors, which can range from the technical and objective (e.g., "frequent use of metaphor") to the vague and subjective (e.g., "a loose, free prose"). What constitutes something like "loose, free prose", in turn, involves a whole host of other criteria, ranging from sentence length to word choice to clause complexity to types of imagery. There is no single, universally accepted point at which a sentence becoming slightly longer or an additional use of imagery turns a text's description from rigid into loose prose. Rather, a text can be described in a whole host of ways using explicitly stated criteria, which can be compared with another text described in the same terms, and the two texts can be then described as more or less "loose", for example, in their prose. Using a host of specific criteria also allows for further, more specific conclusions: where and in which ways the two texts are similar or different; the ways the two texts contain certain criteria clustered together or spread far apart; how the authors pair which criteria with their particular elements of content; and so on.

Polythetism contrasts with essentialized classification, whereby a single or a small set of criteria are considered "essential". Essential characteristics denote that their presence is necessary and sufficient for the object to be considered part of a category. Essentialized classification is thus simpler and clearer than polythetic classification: the issue simply becomes a yes-or-no question, namely whether or not a piece of data has all of the characteristics deemed "essential" to this category. ${ }^{8}$ In the case of Paul's letters, an essentialized form of description or classification would describe his letters as Jewish or Greek or Christian, with a totalizing worldview ascribed to each. ${ }^{9}$ Such essentialized approaches tend to think of these categories (Jewish, Greek, Christian) in mutual exclusion to one another (Paul, in this view, is notable as the rare figure

8 For further discussion of how essentialism is tied to underlying cognitive-epistemological processes, see Rehder, Bob, "Essentialism as a Generative Theory of Classification", in: Causal Learning: Psychology, Philosophy, and Computation, eds. Gopnik, Alison and Schultz, Laura, Oxford: Oxford University Press, 2007, 190-207. See further discussion of different theories of essentialism in Rehder, Bob, and Kim, ShinWoo, "Classifying with Essentialized Categories", in: Proceedings of the 28th Annual Conference of the Cognitive Science Society, eds. Run, Robert, Miyake, Naomi, Mahwah, NJ: Erlbaum, 2006.

9 Some scholars have attempted to reclaim Paul's "Jewishness", e.g. Boyarin, Daniel, A Radical Jew: Paul and the Politics of Identity, Berkeley: UC Press, 1994. And Nanos, Mark D., The Mystery of Romans: The Jewish Context of Paul's Letter, Minneapolis: Fortress, 1996. Underlying this approach is the general attitude that there is a divide between essentialized entities of Hellenism and Judaism, e.g. Sanders, E.P., "Paul between Judaism and Hellenism", in: St. Paul among the Philosophers, eds. Caputo, John D., Alcoff, Linda Martin, Bloomington \& Indianapolis: Indiana University Press, 2009, 74-90. 
straddling and combining these purportedly disparate worlds), instead of a wider ancient Mediterranean milieu with a host of types of beliefs and practices (gods as interested parties, piety linked to virtue, sacrifice, etc.) held in common.

Objects of study can be productively described via both polythetic and essential classification. In biology, for example, mammals are described according to a few "essential" criteria, such as the presence of hair and mammary glands with which they feed their offspring. Particular species, meanwhile, are often defined polythetically, due to the fact that species lines are often fuzzy, subject to hybridity, uncertainty, and change. Different dog breeds, for example, are typically defined as having a minimum of certain criteria, with outliers always possible. An entirely white German Shepherd, for instance, is still considered a member of that breed (i.e., category) despite lacking the typical coloration, as it possesses sufficient other characteristics that comprise that polythetic category.

Polythetism has been effectively deployed in not only biological taxonomies of speciation, ${ }^{10}$ but also philosophical-epistemological typologies such as Ludwig Wittgenstein's notion of "family resemblances" in his "philosophical investigations" around the specific subject of language. ${ }^{11}$ Indeed, while the notion of species has been increasingly questioned, ${ }^{12}$ Wittgenstein's ideas have been productively applied to biological data as an epistemological foundation for retaining modified species concepts. ${ }^{13}$ Polythetism has also been used in other spheres related to epistemology, such as cognitive psychology with respect to knowledge/concept formation. ${ }^{14}$ Specific methodological

10 The touchstone introductory theorization comes from Mayden, Richard L., "A Hierarchy of Species Concepts: The Denouement in the Saga of the Species Problem", in: Species: The Units of Biodiversity, eds. Claridge, M.F., Dawah, A.H., Wilson, M.R., Allemagne: Springer, 1997. For biological epistemologies around taxonomy and speciation, see the useful introduction and discussion in Richards, Richard A., "Species and Taxonomy", in: The Oxford Handbook of Philosophy of Biology, ed. Ruse, Michael, Oxford: Oxford University Press, 1998, 161-188.

Wennerberg, Hjalmar, "The Concept of Family Resemblance in Wittgenstein's Later Philosophy”, Theoria 33.2, Oxford: Blackwell Publishing, 1967, 107-132. The so-called "species problem" in biology goes back at least decades: see the essays in Zachos, Frank E., SpeciesConcepts in Biology: Historical Development, Theoretical Foundations and Practical Relevance, Basel: Springer, 2016.

Pigliucci, Massimo, "Species as Family Resemblance Concepts: The (Dis-)Solution of the Species Problem?", BioEssays 25.6, United Kingdom: Wiley, 2003, 596-6o2.

14 Rosch, Eleanor, and Mervis, Carolyn, B., "Family Resemblances: Studies in the Internal Structure of Categories", Cognitive Psychology 7, Amsterdam: Elsevier, 1975, 573-605. 
work has been done in applying notions from biological polythetism to literary studies, ${ }^{15}$ notably given my research's focus around categories from literature. ${ }^{16}$

Polythetism, in other words, is useful in classifying and comparing complex sets of data whose particular boundary lines might be unclear. The analogy to the social, historical, and literary worlds is obvious, as society, history, and literature are extremely messy, complex, nuanced, and highly subject to change. ${ }^{17}$ Essentialism, meanwhile, seems to fall short both in view of the evidence (with common practices and beliefs across the ancient Mediterranean $)^{18}$ and in light of long-standing methodological critiques. ${ }^{19}$ Indeed, few scholars would still assert that Judaism and Hellenism are entirely mutually exclusive, or that they are distinct and perfectly bounded worldviews; all the more reason, it seems, to dig deeper into polythetic modes of description and classification.

\section{Data: Findings and Visualization}

In my fuller study, I compared Paul's letters with a host of texts, finding the closest similarities with Epictetus' Discourses, Philodemus' On Death and On Piety, and several others: Seneca's Natural Questions, Letter to the Hebrews, and 4 Maccabees. These texts have little redactional overlap, meaning direct textual influence, with the exceptions of Paul's letters probably directly influencing the Letter to the Hebrews, ${ }^{20}$ and Seneca's Natural Questions perhaps influenc-

15 Alastair Fowler has been a notable defender of the utility of biological analogy from the perspective of literary studies, e.g. Alastair Fowler, "Transformations of Genre," in: Modern Genre Theory, ed. David Duff, Harlow, England; New York: Longman, 2000, 232-249.

16 A lengthier discussion of methodological application can be seen in Robertson, Paul's Letters, 89-120.

17 Recently on classifying ancient orphic practices polythetically: Edmonds III, Radcliffe G., Redefining Ancient Orphism: A Study in Greek Religion, Cambridge: Cambridge University Press, 2013.

18 Becker, Adam H., and Yoshiko Reeds, Annette, eds., The Ways That Never Parted:Jews and Christians in Late Antiquity and the Early Middle Ages, Minneapolis: Fortress, 2007.

19 For a review of these methodological critiques, and a charitable conclusion regarding the utility of certain kinds of essentialist thinking, see Sayer, Andrew, "Essentialism, Social Constructionism, and Beyond", The Sociological Review 45, United Kingdom: Wiley, 1997, 453-487.

20 There is general consensus that Hebrews was written in direct imitation of Paul's authentic (as well as other, not surviving) letters: Rothschild, Clare K., Hebrews as Pseudepigraphon: The History and Significance of the Pauline Attribution of Hebrews, Tübingen: Mohr Siebeck, 2009. 
ing Epictetus' Discourses. ${ }^{21}$ The relationship between Paul's letters, Epictetus' Discourses, and Philodemus' texts, in other words, stems from their shared participation in what I term a socio-literary sphere, which is a shared social field of similar types of practices (text production, educated argumentation and group construction), knowledge claims (about the cosmos, about their personal exemplarity and authority), and literary style (use of examples, argument, exhortation) present across the wider milieu of the ancient Mediterranean. ${ }^{22}$

The socio-literary sphere containing Paul's letters, Epictetus' Discourses, and Philodemus' On Death and On Piety, as well as other texts, can be defined polythetically, through a set of twenty characteristics that I term "literary criteria". These characteristics include not only some formal, rhetorical criteria (metaphors) but also aspects of content (universal claims) and social purpose presumably indexed to the authors' activity in the social world (exhortation). These three elements - form, content, and social purpose - intersect in a complex fashion to constitute an author and text's overall style. ${ }^{23}$ Derived inductively and tested deductively through many readings of the extant primary sources in Greek and Latin around Paul's time based on the general criterion of what was notable about any given text, the list is comprised of the following:

Universal Claims or Assertions - general knowledge claims about gods, cosmos, nature, etc.

Appeals to Authority - mentioning texts, authors, and/or divine beings that grant authority to the author's claims

Conversation - incidences where the author engages with his audience directly

Prosópopoiia/Éthopoiia - specific use of this ancient rhetorical tactic

Rhetorical Questions - use of questions for the same argument

Metaphors or Analogies - linking or explaining a situation or argument via these rhetorical tactics

Epictetus doesn't seem to mention Seneca directly; rather, the two draw from the same, earlier Stoic material such as Chrysippus: Bonhöffer, Adolf F., The Ethics of the Stoic Epictetus, translation Stephens, William O., New York: Peter Lang, 1996 (1894), esp. 3. turn on certain types of ideas and social behavior present in their shared, ancient Mediterranean milieu, instead of a direct, specific influence: Glad, Clarence E., Paul \& Philodemus: Adaptability in Epicurean \& Early Christian Psychagogy, Leiden: Brill, 1995. Glad's work is a fine example of how certain types of ideas and social practices occur within a wider field that includes authors purportedly separable according to essentialized categories such as Jewish, Greek, Christian, etc.

Further discussion in Robertson, Paul's Letters, 72-120. 
Anecdotes or Examples - use of concrete argumentative supports Imperatives - commands for the audience to perform a type of action Exhortation - general encouragement towards types of behavior Caustic Injunctions - insults or strong critiques Pathos - use of suffering and/or emotion as a rhetorical tactic Irony or Satire - deployment of these within a wider framework Hyperbole - over-emphasis of a given position or idea to make a point Oppositions or Choices - framing an issue in binary terms, often in an overly generalized way

Figurations of Groupness - constructions of social groups, often around a particular attitude, belief, or behavior

Plural Inclusive versus Second Person Address - different types of address, either directly (their own word) or combined into a verb

First Person Reflection - author injecting their own voice and perhaps example or experience

Analysis of Potential Questions or Objections - specific examination and often refutation of contrary positions/ideas

Systematic Argument - careful logical analysis around an idea

To manifest an empirical comparison based on this polythetic description, each text in question needs to be coded according to the above criteria. Most simply, this can be done by citing where in the text each characteristic occurs. As the above categories are not specific words or grammatical constructions, they cannot be machine read and must be hand coded, which is to say this work needs to be done manually, with a trained eye carefully moving through each text. While much useful research has been conducted on feature selection in data mining that is applicable to digital humanities approaches, ${ }^{24}$ such purely quantitative approaches cannot (yet) capture the type of qualitative judgment necessary to identify characteristics such as pathos, satire, systematic argument, or what constitutes an epistemological claim. As these kinds of second-order characteristics are thus identifiable only by a trained human reader, it is through combining digital tools with informed, primary source analysis that we can achieve proper coding.

For 1 Corinthians, this is what this type of coding looks like:

24 E.g., Wrapper selection and Filter selection. Introductory discussion in Witten, Ian H., and Frank, Eibe, Data Mining: Practical Machine Learning Tools and Techniques, San Francisco: Morgan Kaufmann, 2005. Further discussion in Guyon, Isabelle, and Elisseef, André, "An Introduction to Variable and Feature Selection", Journal of Machine Learning Research 3, United States of America: MIT Press, 2003, 1157-1182. 
TABLE 8.1 1 Corinthians hand-coded textual locations; (CPAULROBERTSON

\section{Characteristic}

Universal claims or

Assertions such as about 4.1?, 4.5, 4.20, 6.13-14, 6.17, 6.18, 7.1ff, 7.10, 7.14, 7.19-20, the gods

Appeals to authority

\section{Conversation}

Personification

Rhetorical questions

Metaphors

Anecdotes or Examples

Imperatives

Exhortation

Caustic injunctions

Pathos

Irony or Satire

Hyperbole

Oppositions or Choices

\section{Location}

$1.8-9,1.18,1.21$ f, $1.25,1.27$ f, 2.1 of, $2.14-15,3.19,3.22-23$, $7.24,7.31,7.39,8.4,8.6,8.8,10.1-6,10.13,10.17,11.3 f$, 11.8-9, 11.11-12, 11.27, 11.32?, 12.3?, 12.4-11, 12.13 , $12.18,12.27,12.28,13.4-8$ ?, 13.13?, 15.2?, 15.3f, 15.16f, 15.20f, 15.39-41, 15.42-4, 15.46f, 15.50, 15.51-54 $1.1,1.6,1.17,1.19,1.31,2.2 f, 2.7,2.9,2.16,3.10,3.19-20$, 4.1, 4.4, 4.6, 4.20, 5.4f, 6.16, 7.10, 7.15, 7.40, 9.2, 9.8-9, 9.16, 9.19-23?, 9.27?, 10.2, 10.7f, 10.18, 10.26?, 11.10?, 11.14, $11.23,12.3$ ?, $12.28,14.21,14.33,14.37-8,15.1,15.3$ f, 15.8 , $15.10,15.27,15.33,15.45,15.54-55,16.15$ ? 1.12 f, 3.4, 6.12-13?, 6.15, 10.23, 10.29-30, 14.15?, 15.29 $6.15,10.23$ ?, 10.29-30, 12.3?, 12.21, 14.15?, 15.29 $1.13,1.20,2.11,3.3-4,3.5,3.16,4.7,4.21,5.2,5.6,5.12$, 6.1-4, 6.5-6, 6.7, 6.9, 6.15, 6.16, 6.19, 7.16, 7.27, 8.10, 9.1, 9.4-12, 9.13, 9.24, 10.16, 10.18-19, 10.22, 10.29, 11.13-15, $11.22,12.17,12.19,12.29-30,14.6,14.7-9,14.15,14.16$, $14.23,14.26,14.36,15.32$ 3.2, 3.6f, 3.1 of, 5.6f, 9.7, 9.10, 12.12, 12.14f, 13.1, 14.7-9, $15 \cdot 48$ ?, 15.49 ?

2.14f, 3.12f, 6.1, 7.21, 7.32-34, 7.36, 8.2-3, 8.7, 9.7, 10.27f, $12.3,12.14$ f, $13.1-3,14.2-4,14.14,14.24,14.30$ 4.5?, 5.2?, 5.5, 5.13, 6.9f, 6.18, 6.20, 7.27, 7.36?, 10.12, $10.14,10.25,11.1,12.31$ ?, 14.1?, 14.20?, 14.39?, 15.34?, $15 \cdot 58$ ?, 16.2f?, 16.1 of, $16.13-14,16.18$ ? 1.10, 3.21, 4.16, 6.18-20, 7.8-10, 7.17, 7.21, 7.24, 7.29-31, 8.9, 9.24, 10.7, 10.8f, 10.14, 10.24f, 10.29, 10.31-33, 11.1, 11.6f, 11.28, 11.33-34, 12.31, 14.1, 14.5, 14.12, 14.13?, 14.20, 14.26f, 14.31f, 14.39-40, 15.34, 15.58, 16.13-14, $16.16,16.18$

$5.2,5.6,6.3$ ?, 6.5?, 6.7?, 11.22 ?, 14.36?, 15.34, 15.36, 16.22 1.14 ?, 6.7 ?, $15 \cdot 10,15 \cdot 31-32$

$4.8 \mathrm{f}$

$4.8,4.9 f$

$1.22 f, 2.14-15,4.9 f, 5.8,6.3,6.10-11,7.22,7.32-34,8.1,8.7$, $10.8 \mathrm{f}, 10.20$ 
TABLE 8.1 Corinthians hand-coded textual locations; (PAULrobertson (cont.)

\section{Characteristic}

\section{Location}

Figurations of groupness 1.2, 1.22-25, 4.9-10, 9.13?, 9.19-22, 10.8f, 10.20, 11.16, 15.11 ?

Second person addresses $1.3 \mathrm{f}, 1.5,1.9,1.26,2.1 \mathrm{f}, 3.9,3.18,3.21-22,4.6,4.14,4.17 \mathrm{f}$, 5.1f, 6.1-2, 6.4, 6.11, 6.20, 7.23f, 7.32, 7.35, 8.10, 9.2, 9.12, $10.1,10.13,10.15,10.20-21,11.2,11.13,11.17,11.23$, 11.30, 12.1f, 12.27, 12.31, 14.6, 14.37, 15.1-2, 15.11, 15.34, $15 \cdot 5^{0}, 15.51,16.1 \mathrm{f}, 16.23^{-24}$

Plural inclusive

Addresses

First person reflection

Analysis of questions or Objections

Systematic structure
$1.2,1.8,1.18,1.23,1.30,2.6,2.12 f, 3.9,4.1,4.9 f, 6.3,8.1$,

$8.4,8.6,9.4,9.10,9.12,9.25,10.1,10.8 f, 10.16,10.22$, $11.31-32,12.13,13.9,15.19,15.49,15.51$

1.4, 1.10-11, 1.14-17, 2.1f, 3.1f, 3.10, $4.3 \mathrm{f}, 4.14 \mathrm{f}, 4.17,5.3$, $5 \cdot 7-8,7.6-7,7.8,7.25 \mathrm{f}, 7.32,7 \cdot 35,9.1,9.8,9.15 \mathrm{f}, 9.26-27$, $10.1,10.15,11.1,11.34,14.18-19,15.1-2$ ?, 15.9, 15.10-11?, $15 \cdot 32,16.21$

$7.18,7.21,10.19-20,15.12 \mathrm{f}, 15.29,15 \cdot 35^{-6}$

3.11f?, 3.17, 4.17, 5.1of?, 7.1f, 8.1f, 8.4, 8.7, 8.11-13, 9.3, 9.10, 9.14, 9.19f?, 10.31?, 11.33-34, 12.1f, 12.12f, 12.14f, 12.26, 13.11-12, 14.2-4, 14.9, 14.11-12, 14.13f, 14.16f, 14.22f?, 15.21 f, 15.27 f, $15.42,15 \cdot 56,16.1 \mathrm{f}$

When the data have been thus compiled, further analysis is possible, the most rudimentary of which involves simply tallying the various incidences and then calculating which are most prevalent by comparing the percentage of total criteria any one given characteristic occupies. Where the presence of a given characteristic is uncertain, this was indicated by a question mark (recall the arguably desirable uncertainty of polythetism around the edges of formal categories), and a range of total appearances and therefore percentages appears. Where the presence of a given characteristic seemed to fulfill two categories, I double counted. This problem, of some characteristics being more homogeneous (e.g., analysis of questions/objections vs. systematic structure) while others are more discrete (e.g., first person reflection vs. metaphors/analogies), is inherent to this type of analysis. I have, perhaps inelegantly, here attempted to solve these two problems (uncertainty of appearance; double counting due to homogeneity) by simply taking the average of the aggregate numbers, with the understanding that I am seeking general trends and relationships, and that 
small differences in terms of counting will therefore not substantially change my findings and conclusions.

For 1 Corinthians, this range of aggregate counting, with raw numbers and each characteristic's total appearances as a percentage of the total criteria, appears as follows:

TABLE 8.2 1 Corinthians numerical \& percentage aggregates; CPAULROBERTSON

\begin{tabular}{llll} 
Characteristic & Minimum \# & Maximum \# & Range (\#s, $\%)$ \\
\hline Universal claims or Assertions & 44 & 50 & $44-50 / 11-14 \%$ \\
Appeals to authority & 39 & 46 & $39-46 / 9-13 \%$ \\
Conversation & 6 & 8 & $6-8 / 1-2 \%$ \\
Personification & 4 & 7 & $4-7 / 1-2 \%$ \\
Rhetorical questions & 42 & 42 & $42 / 10-12 \%$ \\
Metaphors & 10 & 12 & $10-12 / 2-3 \%$ \\
Anecdotes or Examples & 16 & 17 & $16-17 / 4-5 \%$ \\
Imperatives & 12 & 23 & $12-23 / 3-6 \%$ \\
Exhortation & 33 & 35 & $33-35 / 8-10 \%$ \\
Caustic injunctions & 5 & 10 & $5-10 / 1-3 \%$ \\
Pathos & 2 & 4 & $2-4 / 0-1 \%$ \\
Irony or Satire & 1 & 1 & $1 / 0 \%$ \\
Hyperbole & 0 & 2 & $0-2 / 0-1 \%$ \\
Oppositions or Choices & 12 & 12 & $12 / 3 \%$ \\
Figurations of groupness & 7 & 9 & $7-9 / 2 \%$ \\
Second person addresses & 43 & 43 & $43 / 10-12 \%$ \\
Plural inclusive addresses & 28 & 28 & $28 / 7-8 \%$ \\
First person reflection & 28 & 30 & $28-30 / 7-8 \%$ \\
Analysis of questions & 6 & 6 & $6 / 1-2 \%$ \\
or Objections & & 31 & $26-31 / 6-9 \%$ \\
Systematic structure & & &
\end{tabular}

Hand-coding all of Paul's letters can be done according to the same system. At that point, the relative percentages of each characteristic can be averaged to capture the shape of Paul's letters on the whole, here the seven undisputed letters along with 2 Thessalonians: ${ }^{25}$

25 I include 2 Thessalonians as I judge it to be an authentic Pauline letter, due to the ancient evidence (Marcion's alleged canon, the Muratorian Fragment, Irenaeus, Ignatius, Justin, Polycarp) and following certain modern scholars (e.g., Bruce Metzger). However, its status 
TABLE 8.3 Paul's letters average percentages; (CPAULROBERTSON

\begin{tabular}{|c|c|c|c|c|c|c|c|c|c|}
\hline $\begin{array}{l}\text { Characteristics, } \\
\text { high to low }\end{array}$ & Avg \% & Rom & 1Cor & 2 Cor & Gal & 1Thess & 2Thess & Phil & Philemon \\
\hline Universal claims & 12 & 15.5 & 12.5 & 10.5 & 12.5 & $13 \cdot 5$ & 7 & 9 & o \\
\hline Appeals to authority & 11 & 12 & 11 & $15 \cdot 5$ & 8.5 & 7 & 6 & 13 & 25 \\
\hline Second person & 10 & 8.5 & 11 & 7 & 8.5 & 4.5 & 38 & $4 \cdot 5$ & 8.5 \\
\hline \multicolumn{10}{|l|}{ Addresses } \\
\hline Rhetorical questions & 9 & 8.5 & 11 & 7 & 8.5 & 3 & 1.5 & 1.5 & o \\
\hline Plural addresses & 8 & 10.5 & $7 \cdot 5$ & 8 & 8 & $4 \cdot 5$ & $25 \cdot 5$ & 3 & o \\
\hline Exhortation & 8 & 5 & 9 & 8 & 7 & 15 & 8.5 & 14 & $17 \cdot 5$ \\
\hline Systematic argument & 6 & $7 \cdot 5$ & $7 \cdot 5$ & 6.5 & $4 \cdot 5$ & 3 & 2.5 & 6 & $5 \cdot 5$ \\
\hline First person reflect. & 6 & $5 \cdot 5$ & $7 \cdot 5$ & $5 \cdot 5$ & 7 & 3 & 1.5 & 10 & 23 \\
\hline Oppositions & 5 & 2.5 & 3 & $5 \cdot 5$ & $7 \cdot 5$ & 12.5 & $7 \cdot 5$ & 8.5 & o \\
\hline Groupness & 4 & 6 & 2 & 2 & 7 & 11.5 & 5 & 4.5 & 8.5 \\
\hline Examples & 4 & 6 & 4.5 & 2.5 & 6 & 3 & 1 & 4.5 & o \\
\hline Imperatives & 4 & 1.5 & $4 \cdot 5$ & 3.5 & 2 & 2 & 8.5 & 11 & 8.5 \\
\hline Pathos & 3 & 0.5 & 0.5 & 8.5 & 2 & 8.5 & 1.5 & 11 & 14 \\
\hline Questions/Objections & 3 & 5 & 1.5 & 3.5 & 3 & o & o & 1.5 & $5 \cdot 5$ \\
\hline Metaphors & 2 & 1.5 & 2.5 & 4 & 2 & 7 & o & o & o \\
\hline Conversation & 1 & 2 & 1.5 & 0.5 & 1 & 1.5 & o & o & o \\
\hline Hyperbole & 1 & 0.5 & 0.5 & 2.5 & 3 & o & o & 1 & o \\
\hline Prosópopoiia & 1 & 1 & 1.5 & 0.5 & 1 & 1.5 & o & o & o \\
\hline Caustic injunctions & 1 & o & 2 & 0.5 & 2 & o & o & o & o \\
\hline Irony or Satire & o & o & 2 & o & o & o & o & o & o \\
\hline
\end{tabular}

This data can then be graphed to visually depict the overall "shape" of Paul's letters according to this particular polythetic description. The characteristics are arranged from low to high, according to the overall average of all Paul's letters, to show the extent to which each letter departs from this average. This somewhat rudimentary comparison of averages affords us an easily interpretable visualization of each text's shape, which allows for a generalized, comparative view across texts.

This bar-graph, focusing on counting the total incidences, shows the general trend from low to high and how each of Paul's letters roughly conform to the

as genuinely Pauline is strongly disputed, and below I discard the letter in my graphical comparisons in consideration of this debate to avoid distraction from my main points about overlaps/divergences between Paul's letters and other texts here discussed. 


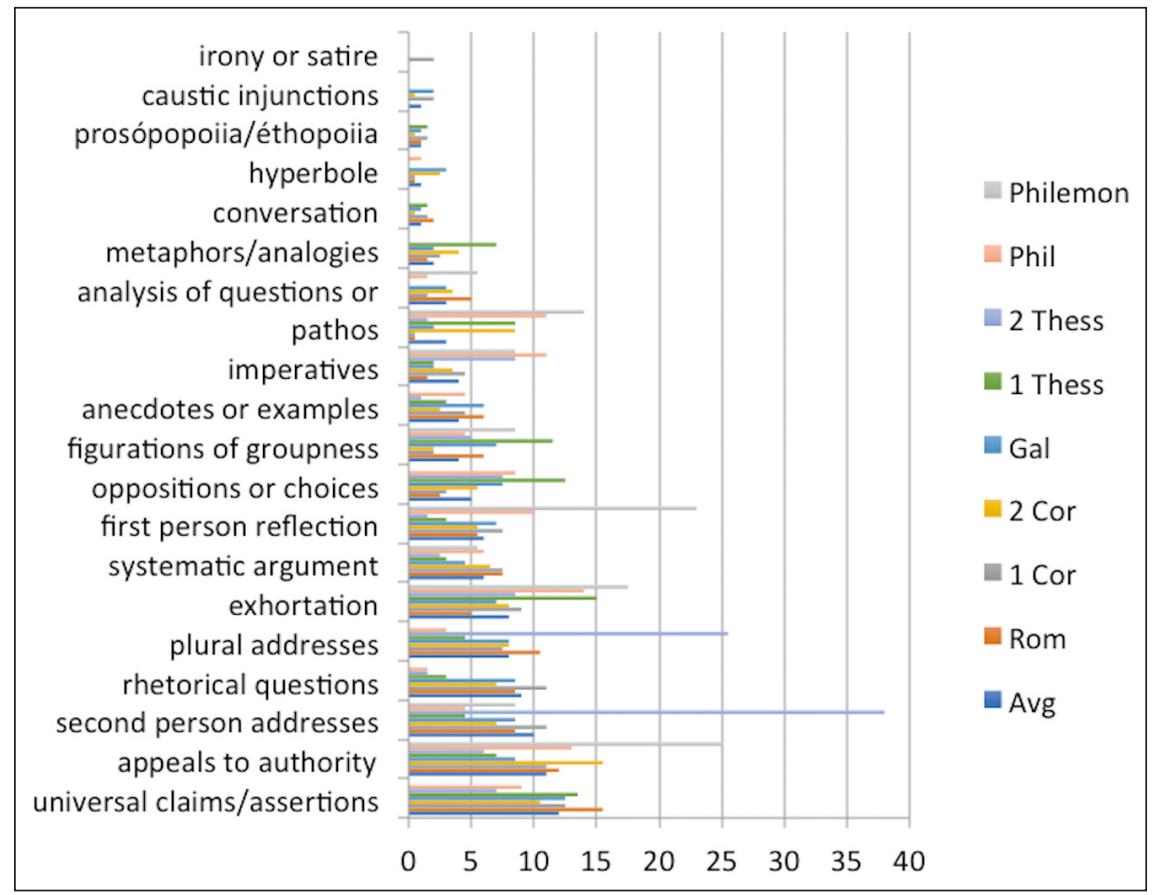

FIGURE 8.1 Paul's Letters Average Percentages: bar graph low to high

average, with notable outliers in Philemon and 2 Thessalonians. The same data can also be visualized differently as a line graph, noting that this is not an expression of a mathematical function but rather still simply as counting total incidences.

Removing 2 Thessalonians (contested authenticity) and Philemon (extremely short length resulting in data outliers due to small sample size) results in an even clearer picture of the way that Paul's letters cluster around each other. This clustering supports the contention that they are of a given type and belong all in the same socio-literary sphere. As a polythetic classification, meanwhile, we note some outlying data points in 1 Thessalonians and Philippians, which in this understanding are less typical of Paul's overall style, while some data points in Romans, 1 Corinthians, and Galatians more closely conform to the average and can be considered more typical of Paul's overall style.

With Paul's letters thus mapped, we can now turn to a comparison of other roughly contemporary texts, in the form of Epictetus' Discourses and Philodemus' On Piety and On Death. The same method for hand-coding these texts is performed, with the following results: 


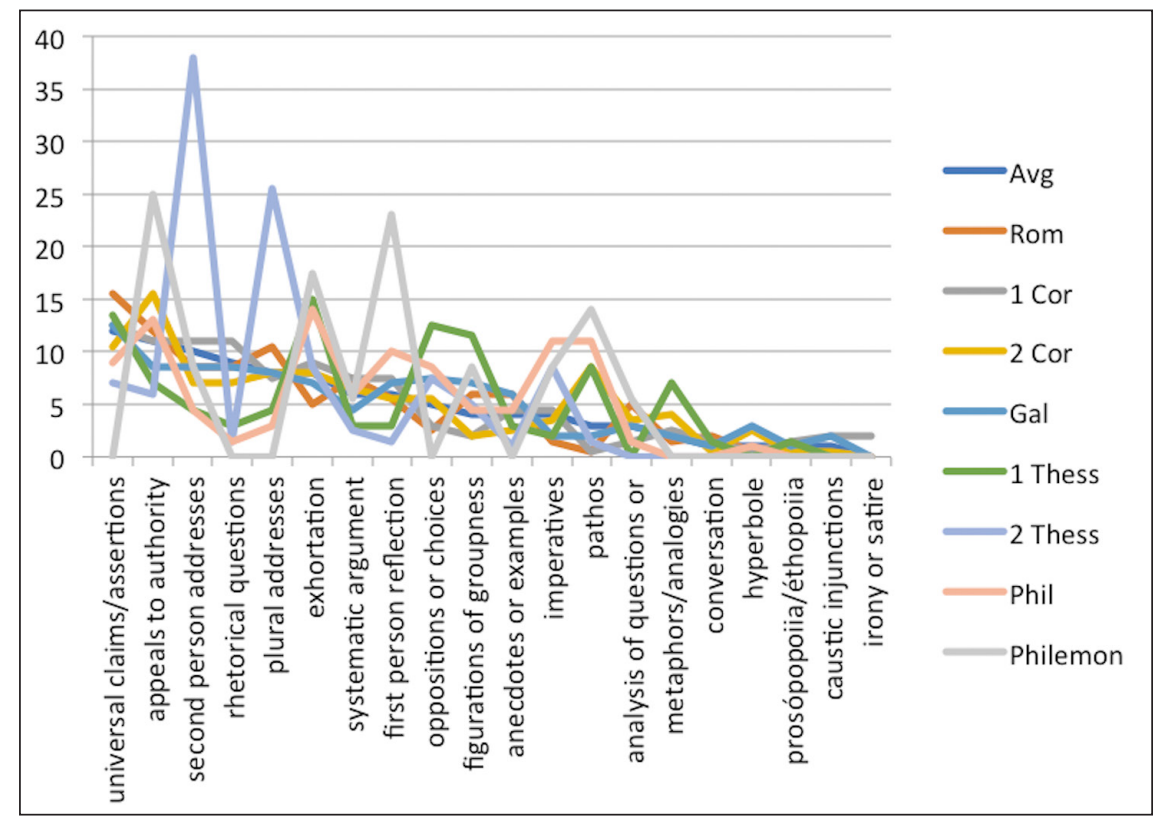

FIGURE 8.2 Paul's letters average percentages: line graph high to low

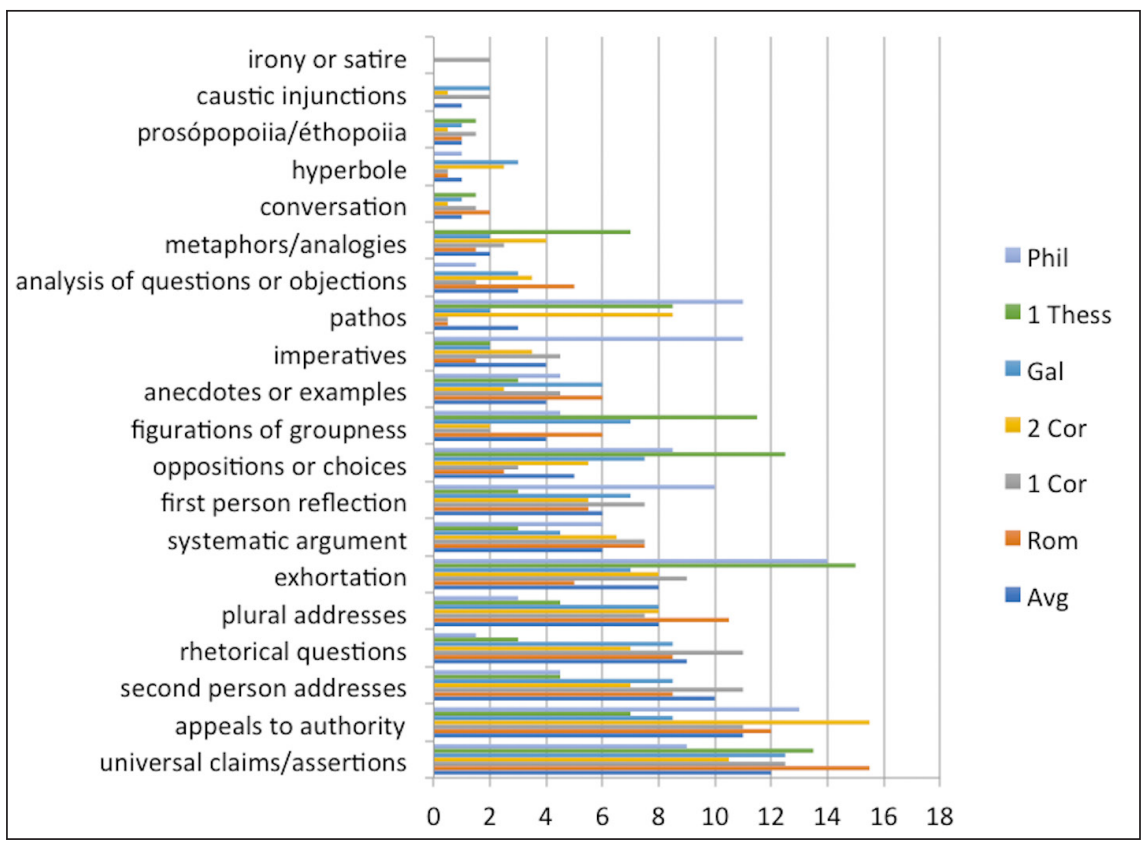

FIGURE 8.3 Paul's letters average percentages bar graph less 2 Thessalonians and Philemon 


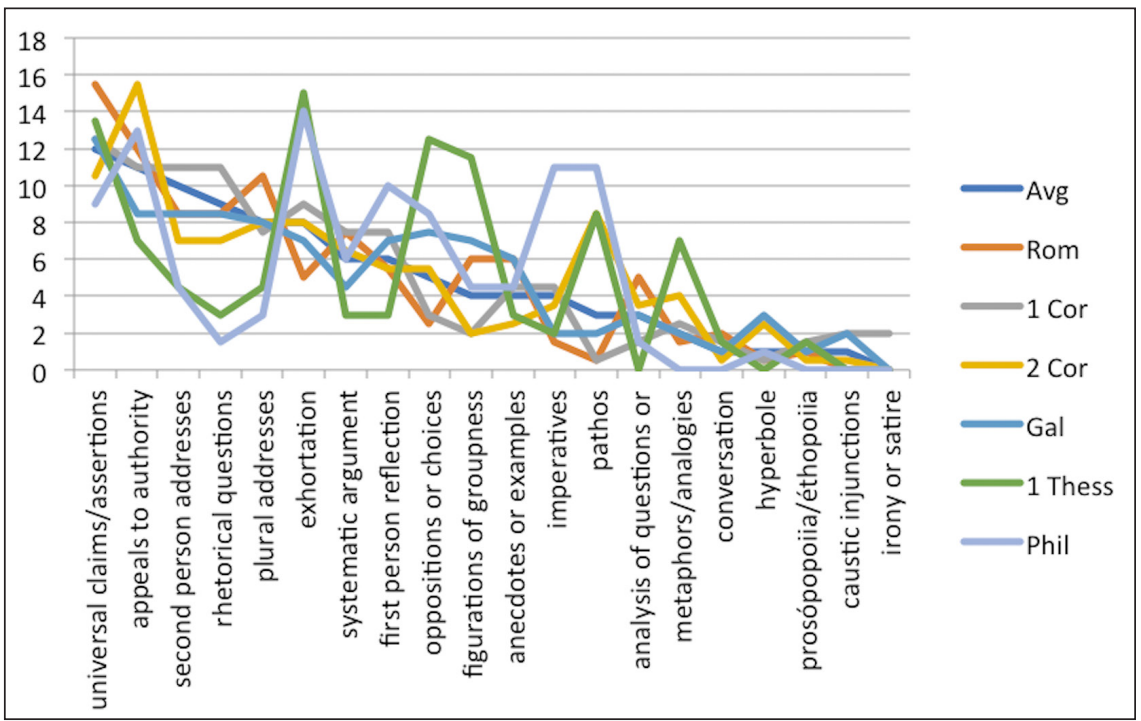

FIGURE 8.4 Paul's letters average percentages line graph less 2 Thessalonians and Philemon; (C) PAULROBERTSON

TABLE 8.4 Average percentages: Paul's letters, Philodemus, Epictetus

\section{Characteristic}

(w/average $\%)$

\section{Paul's letters Philodemus' Philodemus' Epictetus'}

On Death On Piety Discourses
Universal claims/Assertions $\quad 12$

Appeals to authority

Second person addresses

Rhetorical questions

Plural addresses

Exhortation

Systematic argument

First person reflection

Oppositions or choices

Figurations of groupness

Anecdotes or examples

Imperatives

Pathos

Analysis of questions/

Objections

Metaphors/analogies

Conversation
12

11

10

9

8

8

6

6

5

4

4

4

3

3

2

1
6.5

6.5

1

4.5

8.5

1

20

1.5

6.5

12

18.5

o

4

11

o

1

1.5

o
7.5

4.5

4.5

4.5

14

$5 \cdot 5$

8

8.5

2

6.5

3.5

10.5

2.5

o

8.5 
TABLE 8.4 Average percentages: Paul's letters, Philodemus, Epictetus (cont.)

\begin{tabular}{|c|c|c|c|c|}
\hline $\begin{array}{l}\text { Characteristic } \\
\text { (w/average \%) }\end{array}$ & Paul's letters & $\begin{array}{l}\text { Philodemus' } \\
\text { On Death }\end{array}$ & $\begin{array}{l}\text { Philodemus' } \\
\text { On Piety }\end{array}$ & $\begin{array}{l}\text { ' Epictetus' } \\
\text { Discourses }\end{array}$ \\
\hline Hyperbole & 1 & o & 0.5 & 0.5 \\
\hline Prosópopoiia/Éthopoiia & 1 & o & 0.5 & 3 \\
\hline Caustic injunctions & 1 & 6 & $7 \cdot 5$ & $3 \cdot 5$ \\
\hline Irony or Satire & o & 1 & 0.5 & 2.5 \\
\hline
\end{tabular}

Visualized graphically, one can thus compare the shape of these texts in terms of the extent to which they belong in this polythetic category, what I've termed a "socio-literary sphere". Here there is a general, shared trend from low to high, following the average of Paul's letters.

Visualized differently, one can see the comparative shapes in a new light.

Here, Epictetus' Discourses are obviously closer to Paul's letters than the two texts by Philodemus. Philodemus' two texts have some clear outliers around the absence of Second Person Address (absent in both), and the relatively high incidences of Systematic Argument, Figurations of Groupness, and use of Anecdotes/Examples. Nonetheless, even with a graph so closely zoomed in to

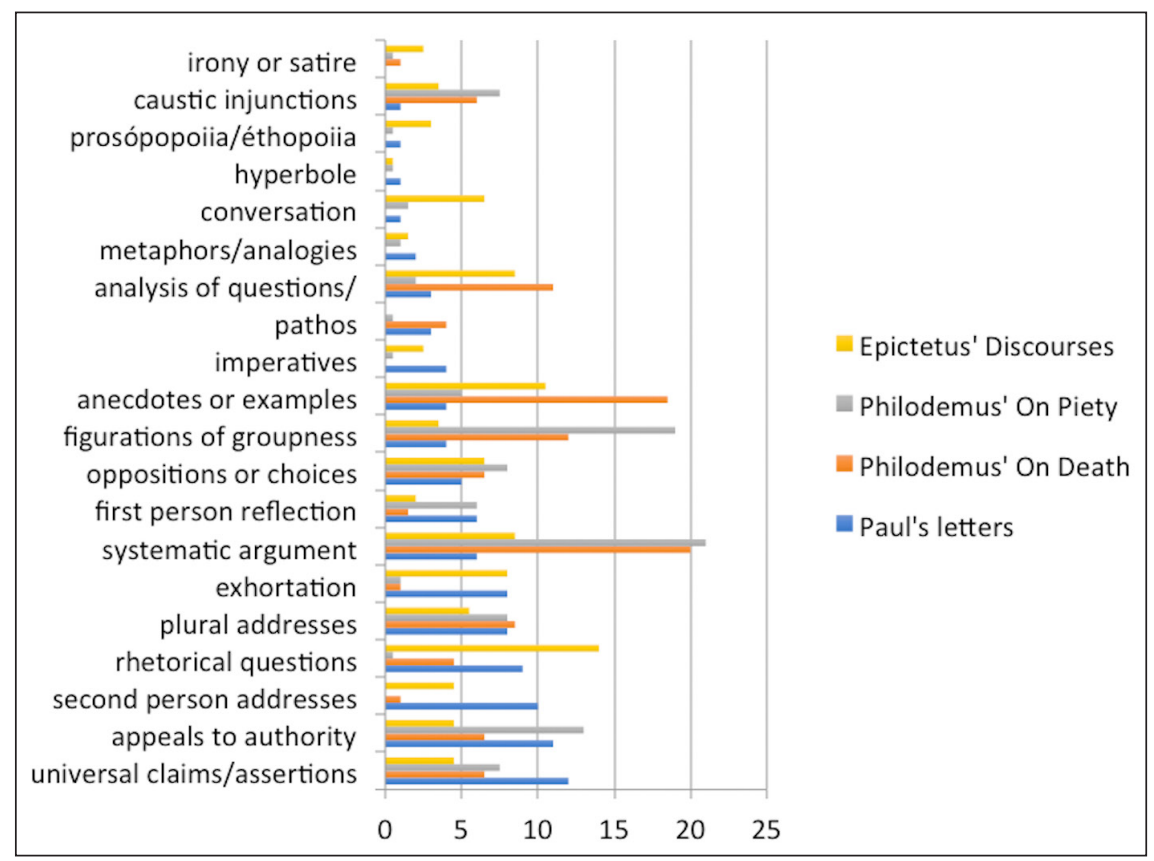

FIGURE 8.5 Average percentages bar graph: Paul, Philodemus, Epictetus; @PAUlroberTson 


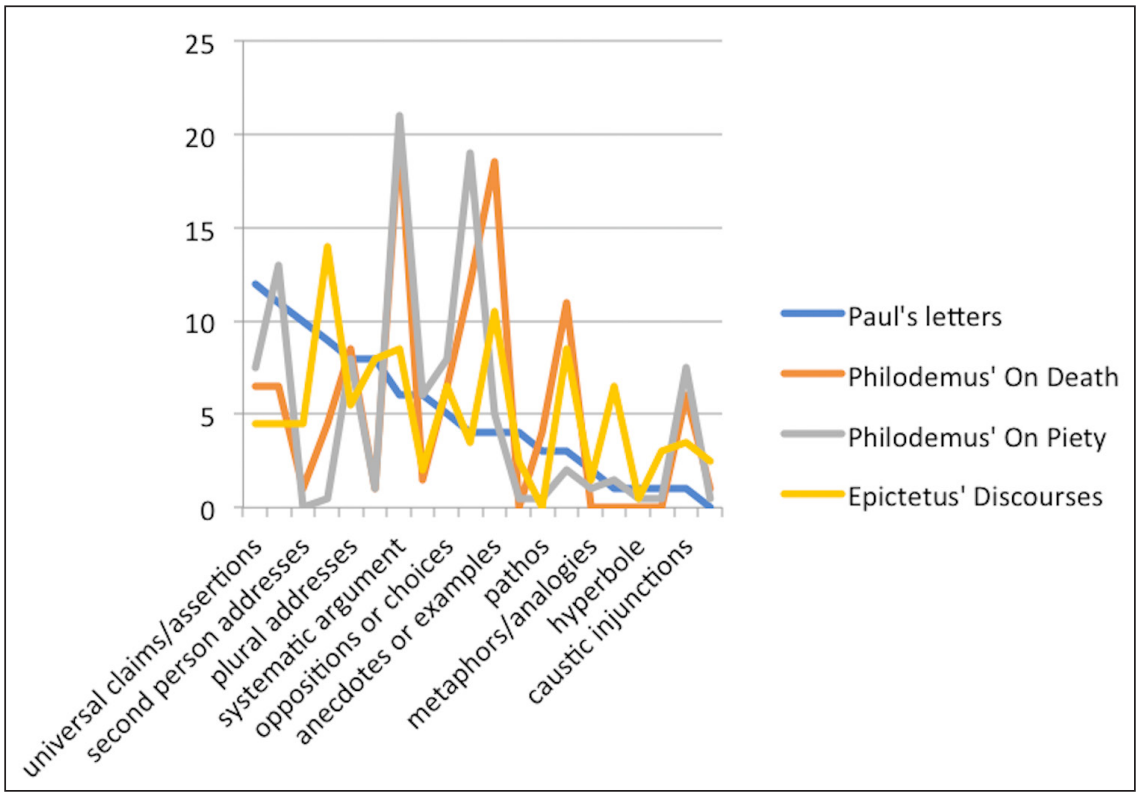

FIgure 8.6 Average Percentages Line Graph: Paul, Philodemus, Epictetus;

(C) PAULROBERTSON

show differences, the general shape of these texts roughly align from left to right, speaking to their general overlaps and thus their belonging to same polythetic category. This conclusion is further strengthened when comparing Paul's letters with other texts, such as Greco-Roman oratory (Aelius Aristides) and Jewish sectarian literature (Damascus Document), likewise hand coded (Table 8.11).

This comparison can be clearly expressed graphically, by comparing the much wider scattering of the data relative to the average of Paul's letters, listed from low to high.

In a different visual form, this becomes further evident. Note again the much wider scattering of these two texts relative to Paul's letters as compared to the texts of Philodemus and especially Epictetus.

4
Literary Criteria in Context: A Case Study of 1 Corinthians, Epictetus' Discourses, and Philodemus' On Piety and On Death

It remains to provide specific readings of the visualized data. As noted, polythetic classification involves deriving second-order characteristics from the primary-source texts, and in this section I explain how this looks in literary 
TABLE 8.5 Average percentages: Paul's letters, Panathenaicus, Damascus Document; CPAULROBERTSON

\begin{tabular}{|c|c|c|c|}
\hline Characteristic (w/average \%) & Paul's letters & $\begin{array}{l}\text { Aelius Aristides' } \\
\text { Panathenaicus }\end{array}$ & $\begin{array}{l}\text { Damascus } \\
\text { Document }\end{array}$ \\
\hline Universal claims/Assertions & 12 & 23 & 21.5 \\
\hline Appeals to authority & 11 & $3 \cdot 5$ & 19 \\
\hline Second person addresses & 10 & 0 & o \\
\hline Rhetorical questions & 9 & 0 & o \\
\hline Plural addresses & 8 & 2.5 & o \\
\hline Exhortation & 8 & 10.5 & 4 \\
\hline Systematic argument & 6 & 17 & 11 \\
\hline First person reflection & 6 & o & 2.5 \\
\hline Oppositions or choices & 5 & 0.5 & 10.5 \\
\hline Figurations of groupness & 4 & 0.5 & 2 \\
\hline Anecdotes or examples & 4 & o & o \\
\hline Imperatives & 4 & o & o \\
\hline Pathos & 3 & 0.5 & o \\
\hline $\begin{array}{l}\text { Analysis of } \\
\text { questions/objections }\end{array}$ & 3 & $3 \cdot 5$ & $13 \cdot 5$ \\
\hline Metaphors/analogies & 2 & 0.5 & 19 \\
\hline Conversation & 1 & 5 & 2 \\
\hline Hyperbole & 1 & 4 & o \\
\hline Prosópopoiia/Éthopoiia & 1 & 13 & 1 \\
\hline Caustic injunctions & 1 & 0.5 & o \\
\hline Irony or Satire & o & 14.5 & 7 \\
\hline
\end{tabular}

practice, with specific examples from several of my criteria as they appear in Paul's letters, Epictetus' Discourses, and Philodemus' On Piety and On Death. To do so, I will investigate several of the characteristics most prominent in Paul's letters: Universal Claims/Assertions, Appeals to Authority, and Figurations of Groupness. For each, I will add qualitative analysis to my quantitative analysis from earlier, showing how each author and text manifests these specific literary criteria in the context of their unique content, as well as in the context of their use of the other literary criteria.

\subsection{Universal Claims or Assertions}

Representative Examples: 1 Corinthians, 1:17-31; Epictetus' Discourses, 1.2, 1-4; Philodemus' On Death, 30, 1-17; Philodemus' On Piety, 31 (lines 878-892). 


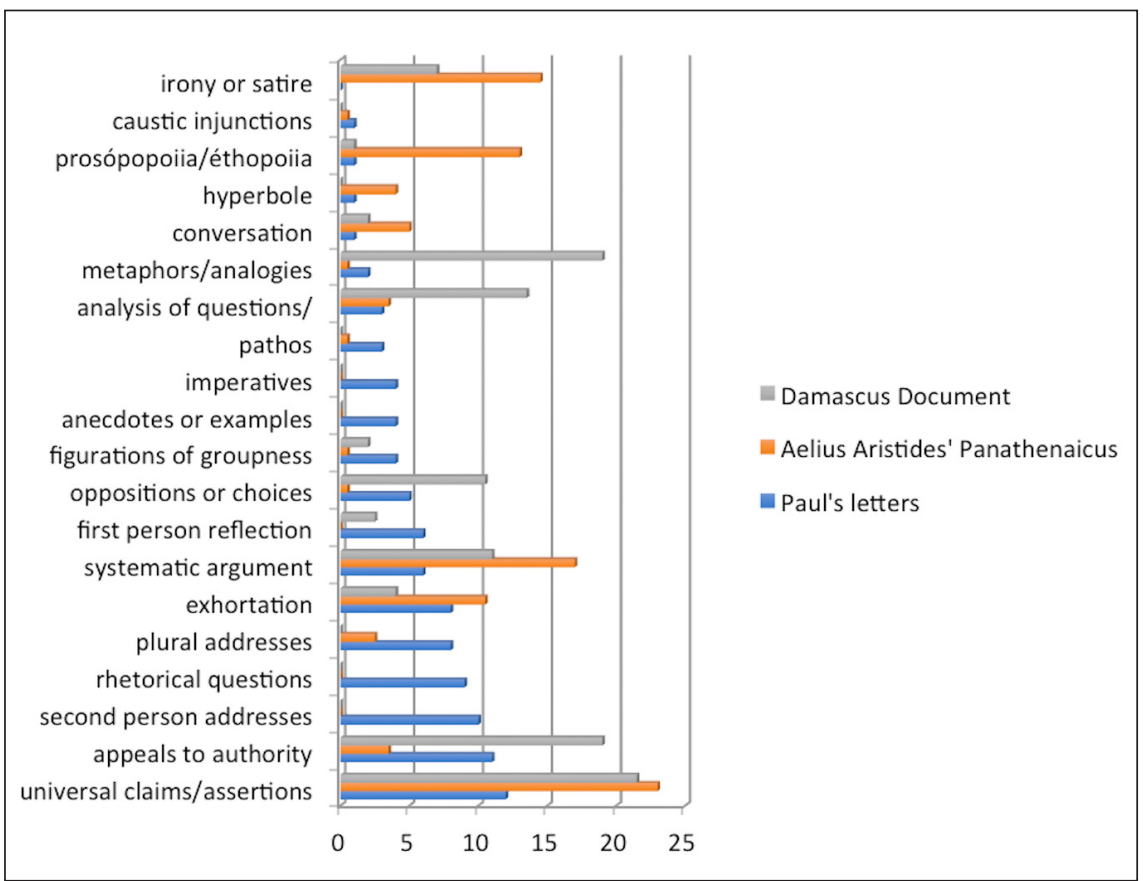

FIGURE 8.7 Averages Bar Graph: Paul's Letters, Panathenaicus, Damascus Document; (c)PAULROBERTSON

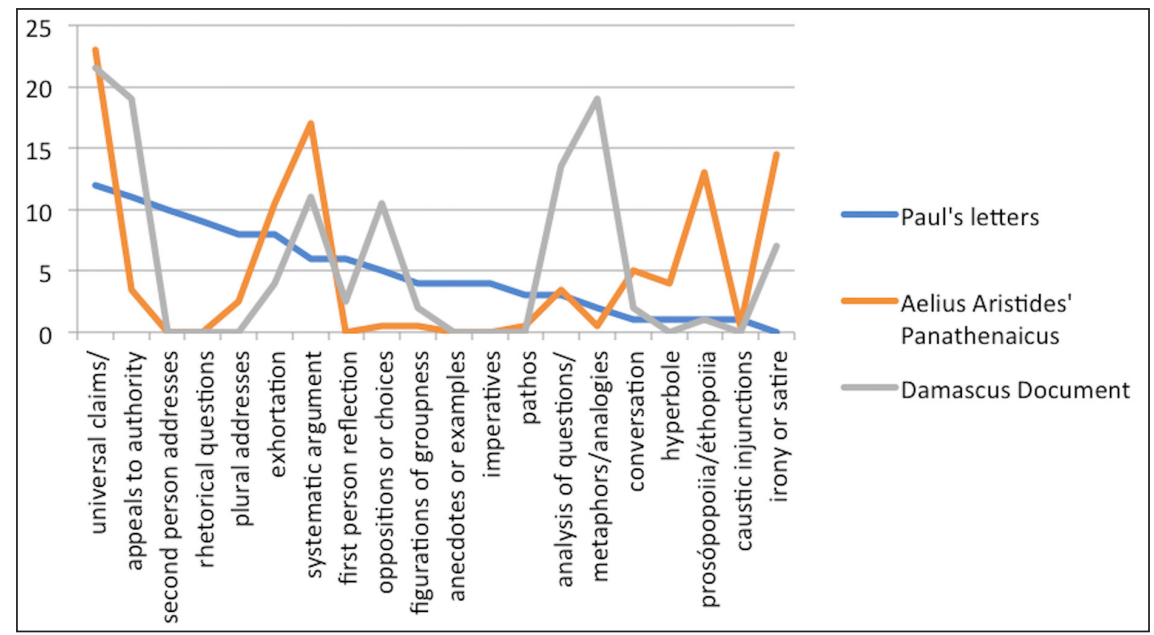

FIGURE 8.8 Averages line graph: Paul's letters, panathenaicus, damascus document; CPAULROBERTSON 


\section{Corinthians, 1:17-31}

For Christ did not send me to baptize but to preach the gospel, and not with eloquent wisdom, lest the cross of Christ be emptied of its power. For the word of the cross is folly to those who are perishing, but to us who are being saved it is the power of God. For it is written, "I will destroy the wisdom of the wise, and the cleverness of the clever I will thwart." Where is the wise man? Where is the scribe? Where is the debater of this age? Has not God made foolish the wisdom of the world? For since, in the wisdom of God, the world did not know God through wisdom, it pleased God through the folly of what we preach to save those who believe. For Jews demand signs and Greeks seek wisdom, but we preach Christ crucified, a stumbling block to Jews and folly to Gentiles, but to those who are called, both Jews and Greeks, Christ the power of God and the wisdom of God. For the foolishness of God is wiser than men, and the weakness of God is stronger than men. For consider your call, brethren; not many of you were wise according to worldly standards, not many were powerful, not many were of noble birth; but God chose what is foolish in the world to shame the wise, God chose what is weak in the world to shame the strong, God chose what is low and despised in the world, even things that are not, to bring to nothing things that are, so that no human being might boast in the presence of God. He is the source of your life in Christ Jesus, whom God made our wisdom, our righteousness and sanctification and redemption; therefore, as it is written, "Let him who boasts, boast of the Lord." (RSV)

This passage contains a host of claims alongside other characteristics, including argument expanding into further claims, first person reflection tied to appeals to authority creating parallel authority claims, examples and rhetorical questions as argument, and the shift between second person addresses when Paul is lecturing/exhorting and plural inclusive addresses when he concludes with general, abstract claims about Christ Jesus and God. We also see here specific groupness (Jews/Judaeans, Greeks, Gentiles) as well as implied groupness constructed around the unobjectionably positive characteristics of wisdom, righteousness, and sanctification, which Paul seems to frame in opposition to those who do not accept his claims ("Jews demand signs and Greeks seek wisdom, but we preach Christ crucified"). Paul here uses the plural inclusive to subsume this opposed groupness beneath his abstract claims ("but we preach Christ crucified ... but to those who are called, both Jews and Greeks, Christ the power of God and the wisdom of God"). This passage concludes with an abstract claim and appeal to authority, which opens up subsequent claims, 
argument, and first person reflection with appeals to authority ( 1 Corinthians, 2:1f.).

Epictetus, Discourses, 1.2, 1-4

To the rational being only the irrational is unendurable, but the rational is endurable. Blows are not by nature unendurable. How so? Observe how: Lacedaemonians take a scourging once they have learned that it is rational. But is it not unendurable to be hanged? Hardly; at all events whenever a man feels that it is rational he goes and hangs himself. In short, if we observe, we shall find mankind distressed by nothing so much as by the irrational, and again attracted to nothing so much as to the rational $[\ldots] \cdot{ }^{26}$

Here we see a typical use of an abstract claim, the movement toward a specific ethical example in the context of argument in support of that claim, and then the move back toward an abstract claim framed in terms of a plural inclusive address. This passage shows the audience how to practically manifest this abstract knowledge about rationality. Clustered in this passage are a host of features standard to the claims-argument-claims form: claims, argument, examples, rhetorical questions, analysis of questions, conversation, and further claims. Epictetus draws a line between himself and his audience, answering a question and using an imperative to direct their attention, and also unites himself with his audience in his concluding, plural inclusive claims.

\section{Philodemus, On Death, 30, 1-17}

[... they disregard (the fact) that all men, including those with as good a physique as Milo [the famous wrestler], become skeletons in a short period of time, and in the end are dissolved into their elementary particles [lit.: 'first natures']: and obviously, analogous points to those stated are to be understood also in the case of bad complexion and bad appearance in general. Now it is very foolish (for men) to be pained foreseeing (that) their burial (will be) not lavish and admired of al but simple and casual ... forgetting both that absolutely all of them are unconscious, or rather do not exist $[\ldots] .^{27}$

26 Epictetus' Discourses, Books 1-2, trans. Oldfather, William Abbot, United States of America: Loeb edition, 1925 .

27 Philodemus, On Death, translation and edition Henry, Benjamin W., Atlanta: Society of Biblical Literature, 2009. 
Though we do not find a clear plural inclusive address paired with a claim, the opposition that Philodemus here draws between his opponents' group ("they") and his group comprised of those accepting his own claims is clear. We here see Philodemus bridging the abstract (his claim that death is a dissolution of particles) and the practical (one shouldn't fear death, and thus shouldn't worry about physical appearances or burial). For Philodemus, these claims and implied exhortations occur within an argument, accusing his opponents of disregarding and forgetting important points (a borderline caustic injunction in his allegation of foolishness), using concrete examples to underpin his further general claims and argument.

\section{Philodemus, On Piety, 31, 878-892}

[...] to conceive of their nature as accurately constituting the notion of benefit according to the epistemological standard. And, lest I extend my discussion, again: "Let us sacrifice to the god", [Epicurus] says, "devoutly and fittingly on the proper days, and let us fittingly perform al the acts of worship in accordance with the laws, in no way disturbing ourselves with opinions in matters concerning the most excellent and august of beings. Moreover, let us sacrifice justly, on the view I was giving. For in this way it is possible for mortal nature, by Zeus, to live like Zeus, as it seems". ${ }^{28}$

For Paul and Epictetus, proper claims are linked to proper behavior and unobjectionably positive qualities and conditions, and we see the same here in Philodemus with piety. The initial abstract claim here is slightly obscured, but seems to refer to the inherent goodness of the gods. Philodemus then immediately turns to Epicurus in an appeal to authority as his argument, showing how even though Epicurus in typical Epicurean fashion believed the gods cared little for humanity, it was still acceptable to worship the gods because they were the embodiment of goodness.

This passage also shows how general claims ('the gods are good') can move into the ethical realm, a bridging of the abstract and the practical likewise present in both Paul and Epictetus. The ethics here are both specific and generalized, as Philodemus (via Epicurus) advocates proper sacrifice to the gods but also generally correct attitude and thoughts regarding the gods. Abstract claims thus manifest in specific ethical matters (sacrificing on the right days) as well as vague but unobjectionably positive behavior (having the right attitudes toward the gods). The use of Epicurus as authority functions as argu-

28 Philodemus, On Piety, trans. and ed. Obbink, Dirk, Oxford: Clarendon Press, 1996. 
ment for Philodemus' claim, and thereby constructs a parallel authority claim in support of Philodemus himself.

\subsection{Appeals to Authority}

Representative Examples: 2 Thessalonians 2:9-15; Epictetus' Discourses, 1.29.3-8; Philodemus' On Death, 23.2-16.

\section{Thessalonians, 2:9-15}

The coming of the lawless one by the activity of Satan will be with all power and with pretended signs and wonders, and with all wicked deception for those who are to perish, because they refused to love the truth and so be saved. Therefore God sends upon them a strong delusion, to make them believe what is false, so that all may be condemned who did not believe the truth but had pleasure in unrighteousness. But we are bound to give thanks to God always for you, brethren beloved by the Lord, because God chose you from the beginning to be saved, through sanctification by the Spirit and belief in the truth. To this he called you through our gospel, so that you may obtain the glory of our Lord Jesus Christ. So then, brethren, stand firm and hold to the traditions which you were taught by us, either by word of mouth or by letter.

Paul here makes a series of abstract claims which he then supports by an appeal to authority, here to God, which Paul then ties to "our gospel" of "the glory of our Lord Jesus Christ" in a parallel authority claim. These claims involve a clear opposition in unobjectionably positive/negative terms, between those who do not accept Jesus and are thereby unrighteous and deluded, and those who accept Jesus and are thereby sanctified and pious. Paul then ties exhortation to the second person address ("stand firm and hold to the traditions which you were taught by us"), a common tie where he sees his audience falling short of his ideal and a tie that highlights his own authority and the ideal manifested in the plural inclusive address. The appeal here occurs in an ethical context, bridging his abstract claims (about Satan and Christ) with concrete behaviors (accepting Paul's teachings in person or in correspondence). Implied in such a formulation is Paul framing himself and his followers ("us") as imitable exemplars who manifest his general claims in the realm of ethics.

\section{Epictetus, Discourses, 1.29, 3-8}

For the judgments about the materials, if they be correct make the moral purpose good, but if they be crooked and awry, they make it evil. This is the law which God has ordained, and he says, "If you wish any good thing, 
get it from yourself." You say, "No, but from someone else." Do not so, but get it from yourself. For the rest, when the tyrant threatens and summons me, I answer "Whom are you threatening?" If he says, "I will put you in chains," I reply, "He is threatening my hands and my feet." ... [I]f I am afraid of any of these threats, it is me he threatens. Who is there left, then, for me to fear? The man who is master of what? The things that are under my control? But there is so such man. ${ }^{29}$

This passage contains a typical form where Epictetus makes a claim, then turns to an appeal to authority to support the claim in addition to a cluster of argument-based characteristics: examples, analysis of questions, rhetorical questions (as argument), and a first person reflection that constructs his own responses in parallel to his appeal to God. Here Epictetus firmly differentiates himself from his audience, faming himself as an imitable exemplar, who brings into the practical realm his abstract claims that are supported by divine appeal. Implicit in this account is Epictetus' exhortation to his audience to accept his abstract claims and put them into practice in examples like he provides here, thereby bridging the macro (general claims) and micro (specific ethical examples). Implicit in this account (and explicit in the lines following, $1.29,9 f$.) is an opposition to those who fear a tyrants' threats (embodied in his second person interlocutor), as Epictetus constructs an oppositional groupness around those who accept his claims and thus embrace his exhortation to respond ambivalently to such threats.

\section{Philodemus, On Death, 23, 2-16}

But if one must judge by the results, who gained protectors such as Polyaenus and Metrodorus and Leonteus and Epicurus himself (gained) from (the moment of) death right up to now, and similarly all those who progressed in our school? And even among laymen we see many obtaining lawful and natural honor to the full extent from friends who displayed noteworthy goodwill, much more than those men (obtain such honor) who left behind the children of Danaus and of his brother and of him who [fathered an even greater number], Heracles, so that there is left over (?) to profit $[\ldots] .{ }^{30}$

Philodemus' appeal to authority is a list of the big names in the early Epicurean school. This appeal occurs in the context of an argument, which Philodemus

29 Epictetus' Discourses, Books 1-2, 1925.

30 Philodemus, On Death, 23, 2-16, trad. Henry, 2009. 
supplements with a rhetorical question and examples. We here see those who behave properly, presumably due to adherence to correct claims, being framed with a plural inclusive address, which Philodemus opposes to the (majority?) group of people who put their stock in mythological examples of behavior. There also appears an implied exhortation, namely that even common people can and should have friends who display goodwill, which Philodemus links up with appeals to law and natural honor, i.e. nature. While we don't find an explicit first person reflection, the use of appeals here surely reinforces Philodemus' own wider argument and claims, which are aligned with those of Epicurus and other early Epicurean leaders. Proper adherence to these claims, in turn, has ramifications in the ethical world, specifically with friendship, as Philodemus uses the examples of his authorities in an appeal to demonstrate the bridge between the abstract and the practical.

\subsection{Figurations of Groupness ${ }^{31}$}

Representative Examples: 1 Corinthians, 11:20-32; Epictetus' Discourses, 1.3, 1-4; Philodemus' On Piety, 75 (see also 77), 2158-2218.

\section{Corinthians, 11:20-32}

When you meet together, it is not the Lord's super that you eat. For in eating, each one goes ahead with his own meal, and one is hungry and another is drunk. What! Do you not have houses to eat and drink in? Or do you despise the church of God and humiliate those who have nothing? What shall I say to you? Shall I commend you in this? No, I will not. For I received from the Lord what I also delivered to you, that the Lord Jesus on the night when he was betrayed took bread, and when he had given thanks, he broke it, and said, "This is my body which is for you. Do this in remembrance of me." In the same way also the cup, after supper, saying, "This cup is the new covenant in my blood. Do this, as often as you drink it, in remembrance of me." For as often as you eat this bread and drink the cup, you proclaim the Lord's death until he comes. Whoever, therefore, eats the bread or drinks the cup of the Lord in an unworthy manner will be guilty of profaning the body and blood of the Lord. Let a man examine himself, and so eat of the bread and drink of the cup. For anyone who eats and drinks without discerning the body eats and drinks judgment upon himself. That is why many of you are weak and ill, and some have died. 
But if we judged ourselves truly, we should not be judged. But when we are judged by the Lord, we are chastened so that we may not be condemned along with the world.

Paul uses the construction of groupness similarly to how he uses oppositions, in that both tend to underpin a shift from specific, concrete, ethical matters to abstract, generalized claims. Here we see Paul move from the discussion of meals and his audience's behavior therein to eating and drinking in memory of Christ generally, from which he then further moves onto the moral issue of judgment and being self-reflective. For Paul, groupness is constructed around specific ethical issues, but seemingly more important is the construction of groupness along general, moral, and abstract lines, specifically whether or not people acted in accordance with proper belief in Christ. Thus groupness constructed around ethical matters is given a deeper valence, tied to unobjectionably positive characteristics such as proper judgment and piety.

This move also extends Paul's authority from concrete, practical matters (who to dine with) to wider, abstract issues (what to believe, what is proper piety and judgment). We thus see the beginning of this passage, with non-ideal behavior, framed with argument, rhetorical questions, examples, appeals to authority, second person addresses, oppositions, and Paul's first person reflection and appeals to authority in a parallel authority claim. This turns, in a fashion common to Paul's letters and the other texts in this same sphere, into a concluding plural inclusive claim that is generalized, unobjectionably positive (judgment by the Lord), and in purportedly line with Paul's broader set of claims.

\section{Epictetus, Discourses, 1.3, 1-4}

If a man could only subscribe heart and soul, as he ought, to this doctrine, that we are all primarily begotten of God, and that God is the father of men as well as of gods, I think that he will entertain no ignoble or mean thought about himself. Yet, if Caesar adopts you no one will be able to endure your conceit, but if you know that you are a son of Zeus, will you not be elated? As it is, however, we are not, but inasmuch as these two elements were comingled in our begetting, on the one hand the body, which we have in common with the brutes, and, on the other, reason and intelligence, which we have in common with the gods, some of us incline toward the former relationship, which is unblessed by fortune and is mortal, and only a few toward that which is divine and blessed. ${ }^{32}$ 
This passage is a prime illustration of how Epictetus constructs a firm groupness based on the binary between those who accept his claims and those who do not. This binary is constructed along the vague but stark difference between the unobjectionably positive versus negative terms, here the difference between "brutes" ("animals", ta zōa) and those with "reason and intelligence" (logos and gnōsis). Epictetus often connects the acceptance of his claims with sound mind and piety, and broaches the ethical realm by talking about how one who has accepted his claims thinks about themselves practically.

We also see in this passage several other common themes, such as the plural inclusive and general claims regarding his ideal, the second person address when directing his attention to someone who may fall short of his ideal, the first person reflection used to foreground the author's authority, and the use of examples, questions, and argument to support a groupness constructed around his claims, which he subsequently expands with regard to claims, argument, examples, groupness, and exhortation $(1.3,4-9)$. Those who fall short of his ideal are subject to both censure and implied exhortation, both to accept his claims and to behave properly, which for Epictetus is a natural correlate.

Philodemus, On Piety, 75 (see also 77), 2158-2181

But the others of course introduced fabulous and terrible stories [about the gods], and did not seem to be introducing these things either in the same way as their predecessors [those who promulgated false tales to secure their own personal security] or as the sources of security to states; and what with, on the one hand conforming to currently prevailing opinions, on the other hand at the same time conceiving inconsistency and madness, they seemed not only impious but also dishonest; and they spoke in opposition (though a philosopher should speak freely) to no one at all; and they did not remotely perceive Epicurus' opinion about the gods, nor state it $[\ldots] .33$

In this passage Philodemus details how groups comprised of those with claims that differ from his own acted in the context of social life. This passage, in the context of Philodemus' wider argument about his claims, details the practical valences of these different groups. Groupness, in other words, is constructed around both claims (what people believe of the gods) and ethics (how people behave based on these claims), as groupness shows its ability to join the abstract to the practical. 
Though Philodemus lacks the shift from the second person address to the plural inclusive claim, a lack that is relatively widespread in Philodemus compared to Paul and Epictetus, this passage does include the implied exhortation born of this type of groupness, here that people should eschew mythological stories and not speak in public unless they are contesting particular points. As is often the case with this and the other texts in this socio-literary sphere, Philodemus seems to construct this groupness as an opposition (in claims and behavior) and ties the sides of this groupness to unobjectionably positive and negative characteristics, here tying the opposed group to inconsistency, madness, impiety, and dishonesty.

\section{5}

\section{Conclusions, Limitations, and Further Study}

In sum, developing a polythetic classification of ancient literature has allowed an empirical, transparent, and quantifiable comparison of literature. This comparison has shown that certain texts by Epictetus and Philodemus are relatively similar to Paul's letters, while texts such as Aelius Aristides' Panathenaic Oration and the Damascus Document are relatively different from Paul's letters. To this quantitative analysis and visualization I added qualitative analysis, exploring how each author and text manifested certain characteristics in the context of their unique content as well as in the context of their use of the other characteristics that comprise the full polythetic classification of this socio-literary sphere.

Hand-coding the data is necessary in order to capture the complex nature of literature, literary style, content, and a nuanced classificatory framework. This hand-coding of the data, despite potential imperfections inherent to polythetic classification, subjective judgment, and the time-intensive nature of such work, nonetheless allows us to visualize a text's shape. This visualization is not only useful descriptively, however, as it also allows for a visual, empirical comparison with other data.

This type of comparative work, which in a certain way quantifies the notion of literary overlap, can test existing theories about literary typologies (e.g., how best to understand Paul's letters by analogy to other texts) as well as suggest new avenues of study (e.g., intersections between Paul, Epictetus, and Philodemus around literary production and their social goals). Given the volume and breadth of the data collected, in this and previous research, there remains a great deal of work to be done in visualizing, analyzing, and applying the data for projects both quantitative and qualitative. The present study provides 
biblical scholars another tool for understanding and approaching literary analysis and comparison.

More specifically, the analysis in this chapter and my previous work relies on univariate numerical description, which is to say I distill my data and figures into single numbers such as an average percentage. In some ways this over-simplifies the data and corresponding visualizations, but by choice: my goal here has been to show how straightforward, accessible tools in programs as simple as Excel can easily be used to test and/or suggest particular claims about literary overlaps and divergences. The data and graphs above, while simplified, are certainly suggestive in a variety of ways discussed above.

But this approach has clear limitations, which in turn opens the door for further analysis. In particular, the multiple-characteristic nature of polythetic classification points to the utility of multivariate (instead of univariate) statistical tools that make use of these robust data points and their potential relations. Potential statistical frameworks and tools are several, including correspondence analysis, biplots, and other types of graphical, fuzzy classification methods. Such tools would not only provide a richer visualization of the textual data as such, but ideally also of the relations between these characteristics and across these texts. As noted in my qualitative discussion above, certain characteristics in my socio-literary seem to cluster together. Multivariate statistical tools may well provide a clearer, and more quantitative, picture of these clusterings.

In particular, my current research program on this data focuses on correspondence analysis, which attempts to show how different categories of data (here my characteristics) correspond to each other in a wider structure. ${ }^{34}$ Such data can be plotted in a variety of ways on two-dimensional graphs, showing both how characteristics cluster together in a given text and how the clustering of characteristics compares across texts. This type of analysis has a history of use in the humanities and social sciences, notably deployed by Pierre Bourdieu (recall my discussion of Bourdieu in my introductory discussion) in his analysis of how his notion of "distinction" manifested across particular social fields. ${ }^{35}$

34 Useful starting points: Michael, Greenacre, Correspondence Analysis in Practice, London: Chapman \& Hall, 2007 (1993); Phillip M., Yelland, "An Introduction to Correspondence Analysis", The Mathetmatica Journal 12, Wolfram, 2010.

35 Pierre Bourdieu, Distinction: A Social Critique of the Judgment of Taste, Cambridge, MA: Harvard University Press, 1984 (1979); see discussion on Bourdieu's quantifying of social data, germane to my discussion here, in Frédéric Lebaron, "How Bourdieu "Quantified" Bourdieu: The Geometric Modeling of Data”, in: Quantifying Theory: Pierre Bourdieu, eds. Karen Robson and Chris Sanders, New York: Springer, 2009, 11-30. 
In addition to my own ongoing research, it is my hope that by making available my data and initial analyses, other scholars so inclined might make use of and build upon them with more sophisticated tools to redress some of the limitations and weaknesses noted here. Such analyses will likely strengthen and expand some of my findings and claims, undermine and reject others, and ideally provide new postulates and suggestions about the structure of these texts and their relationships with each other. These sorts of findings, in turn, will hopefully underpin new claims about the nature of ancient textual production and the foundational link between textual production, textual content, and social activity that I posit as fundamental to any socio-literary sphere.

\section{References}

Alastair, Fowler, "Transformations of Genre”, In: Modern Genre Theory, ed. Duff, David, Harlow, England; New York: Longman, 2000, 232-249.

Becker, Adam H., and Yoshiko Reeds, Annette, eds., The Ways That Never Parted:Jews and Christians in Late Antiquity and the Early Middle Ages, Minneapolis: Fortress, 2007.

Bonhöffer, Adolf F., The Ethics of the Stoic Epictetus, translation Stephens, William O., New York: Peter Lang, 1996 (1894), esp. 3.

Bourdieu, Pierre, Distinction: A Social Critique of the Judgment of Taste, Cambridge, MA: Harvard University Press, 1984.

Bourdieu, Pierre, Outline of a Theory of Practice, Cambridge: Cambridge University Press, 1977 .

Boyarin, Daniel, A Radical Jew: Paul and the Politics of Identity, Berkeley: UC Press, 1994. Brubaker, Rogers, Ethnicity Without Groups, Cambridge: Harvard University Press, 2004.

Edmonds III, Radcliffe G., Redefining Ancient Orphism: A Study in Greek Religion, Cambridge: Cambridge University Press, 2013.

Epictetus' Discourses, Books 1-2, trans. Oldfather, William Abbot, United States of America: Loeb edition, 1925 .

Foucault, Michel, The Archaeology of Knowledge, trans. A.M. Sheridan Smith, New York and London: Routledge, 2002.

Glad, Clarence E., Paul \& Philodemus: Adaptability in Epicurean \& Early Christian Psychagogy, Leiden: Brill, 1995.

Greenacre, Michael, Correspondence Analysis in Practice, London: Chapman \& Hall, 2007 (1993). 
Guyon, Isabelle, and Elisseef, André, "An Introduction to Variable and Feature Selection", in: Journal of Machine Learning Research 3, United States of America: MIT Press, 2003, 1157-1182.

Lebaron, Frédéric, "How Bourdieu 'Quantified' Bourdieu: The Geometric Modeling of Data", in: Quantifying Theory: Pierre Bourdieu, eds. Robson, Karen, Sanders, Chris, New York: Springer, 2009, 11-30.

Mayden, Richard L., "A Hierarchy of Species Concepts: The Denouement in the Saga of the Species Problem", in: Species: The Units of Biodiversity, ed. Claridge, M.F., Dawah, A.H., Wilson, M.R., Allemagne: Springer, 1997.

Nanos, Mark D., The Mystery of Romans: The Jewish Context of Paul's Letter, Minneapolis: Fortress, 1996.

Philodemus, On Death, translation and edition Henry, Benjamin W., Atlanta: Society of Biblical Literature, 2009.

Philodemus, On Piety, trans. and ed. Obbink, Dirk, Oxford: Clarendon Press, 1996.

Pigliucci, Massimo, "Species as Family Resemblance Concepts: The (Dis-)Solution of the Species Problem?", BioEssays 25.6, United Kingdom: Wiley, 2003, 596- 602.

Rehder, Bob, "Essentialism as a Generative Theory of Classification", in: Causal Learning: Psychology, Philosophy, and Computation, eds. Gopnik, Alison and Schultz, Laura, Oxford: Oxford University Press, 2007, 190-207.

Rehder, Bob, and Kim, ShinWoo, "Classifying with Essentialized Categories", in: Proceedings of the 28th Annual Conference of the Cognitive Science Society, eds. Run, Robert, Miyake, Naomi, Mahwah, NJ: Erlbaum, 2006.

Richards, Richard A., "Species and Taxonomy", in: The Oxford Handbook of Philosophy of Biology, ed. Ruse, Michael, Oxford: Oxford University Press, 1998, 161-188.

Robertson, Paul, Paul's Letters and Contemporary Greco-Roman Literature: Theorizing a New Taxonomy, Leiden: Brill, 2016.

Rosch, Eleanor, "Wittgenstein and Categorization Research in Cognitive Psychology", in: Meaning and the Growth of Understanding: Wittgenstein's Significance for Developmental Psychology, eds. Chapman, Michael., Dixon Roger, A., Hillsdale, NJ: Erlbaum, 1987, 151-166.

Rosch, Eleanor, and Mervis, Carolyn, B., "Family Resemblances: Studies in the Internal Structure of Categories", Cognitive Psychology 7, Amsterdam: Elsevier, 1975, 573-605.

Rothschild, Clare K., Hebrews as Pseudepigraphon: The History and Significance of the Pauline Attribution of Hebrews, Tübingen: Mohr Siebeck, 2009.

Sanders, E.P., "Paul between Judaism and Hellenism”, in:St. Paul among the Philosophers, edition Caputo, John D., Alcoff, Linda Martin, Bloomington \& Indianapolis: Indiana University Press, 2009, 74-90.

Sayer, Andrew, "Essentialism, Social Constructionism, and Beyond", The Sociological Review 45, United Kingdom: Wiley, 1997, 453-487. 
Schatzki, Theodore, The Site of the Social: A Philosophical Account of the Constitution of Social Life and Change, Philadelphia, PA: University of Pennsylvania Press, 2002.

Tarot, Camille, Michel Despland, L'émergence des sciences de la religion. La monarchie de Juillet: un moment fondateur, Paris: L'Harmattan, 1999.

Wennerberg, Hjalmar, “The Concept of Family Resemblance in Wittgenstein's Later Philosophy", Theoria 33.2, Oxford: Blackwell Publishing, 1967, 107-132.

Witten, Ian H., and Frank, Eibe, Data Mining: Practical Machine Learning Tools and Techniques, San Francisco: Morgan Kaufmann, 2005.

Yelland, Phillip M., "An Introduction to Correspondence Analysis", The Mathematica Journal 12, United States of America: Wolfram, 2010, 1-23.

Zachos, Frank E., Species Concepts in Biology: Historical Development, Theoretical Foundations and Practical Relevance, Basel: Springer, 2016. 
PART 3

Communication 